\title{
Penggunaan Media Pembelajaran e-Learning Berbasis Web untuk Meningkatkan Hasil Belajar IPA Siswa Kelas VII
}

\author{
Rina Sardiana Sari*1, I Gede Purwana Edi Saputra'2, Muhammad Iqbal Saman ${ }^{3}$ \\ ${ }^{123}$ Universitas Sembilanbelas November Kolaka \\ e-mail: *1 rinasardian4@gmail.com, ${ }^{2}$ gedepurwana@gmail.com ${ }^{3}$ Mr.iqbal17@gmail.com
}

\begin{abstract}
Abstrak
Penelitian ini bertujuan untuk: (1) mendeskripsikan gambaran hasil pre-test siswa kelas eksperimen dan siswa kelas kontrol pada materi pokok suhu dan perubahannya, (2) mendeskripsikan gambaran hasil post-test siswa kelas eksperimen dan siswa kelas kontrol pada materi pokok suhu dan perubahannya, (3) menentukan ada tidaknya perbedaan yang signifikan antara skor rata-rata hasil pre-test siswa kelas eksperimen dengan skor rata-rata hasil pre-test siswa kelas kontrol pada materi pokok suhu dan perubahannya, (4) menentukan bahwa skor rata-rata hasil post-test siswa kelas eksperimen lebih baik secara signifikan dibandingkan dengan skor rata-rata hasil post-test kelas kontrol pada materi pokok suhu dan perubahannya, serta (5) menentukan bahwa skor rata-rata gain (peningkatan) hasil belajar IPA siswa kelas eksperimen lebih baik secara signifikan dibandingkan dengan skor rata-rata gain (peningkatan) hasil belajar IPA siswa kelas kontrol pada materi pokok suhu dan perubahannya. Penelitian ini termasuk dalam penelitian eksperimen kuasi. Subjek uji coba dalam penelitian ini meliputi peserta didik kelas VII SMP Negeri 4 Kendari. Data dikumpulkan melalui lembar observasi aktivitas pembelajaran dan tes hasil belajar. Hasil penelitian menunjukkan bahwa: (1) gambaran hasil pre-test siswa kelas eksperimen pada materi pokok suhu dan perubahannya yaitu diperoleh skor maksimum 43, skor minimum 14, skor rata-rata 24,7 dan standar deviasi 6,89, sedangkan pada kelas kontrol yaitu diperoleh skor maksimum 40, skor minimum 17, skor rata-rata 27,64 dan standar deviasi 6,15, (2) gambaran hasil post-test siswa kelas eksperimen pada materi pokok suhu dan perubahannya yaitu diperoleh skor maksimum 86, skor minimum 51, skor rata-rata 62,86 dan standar deviasi 7,18, sedangkan pada kelas kontrol yaitu diperoleh skor maksimum 63, skor minimum 40, skor rata-rata 50,29 dan standar deviasi 5,89, (3) tidak ada perbedaan yang signifikan antara skor rata-rata hasil pre-test siswa kelas eksperimen dengan skor rata-rata hasil pre-test siswa kelas kontrol pada materi pokok suhu dan perubahannya, (4) skor rata-rata hasil post-test siswa kelas eksperimen lebih tinggi secara signifikan daripada skor rata-rata hasil post-test siswa kelas kontrol pada materi pokok suhu dan perubahannya, (5) skor rata-rata gain (peningkatan) hasil belajar IPA siswa kelas eksperimen lebih tinggi secara signifikan daripada skor rata-rata gain (peningkatan) hasil belajar IPA siswa kelas kontrol pada materi pokok suhu dan perubahannya, yang ditunjukkan oleh skor rata-rata gain kelas eksperimen dan kelas kontrol yaitu sebesar 0,5 dan 0,31.
\end{abstract}

Kata Kunci: Media Pembelajaran e-Learning, Pembelajaran Berbasis Web, Hasil Belajar IPA.

\section{PENDAHULUAN}

Pendidikan merupakan sumber kemajuan bangsa yang sangat menentukan daya saing antar bangsa. Oleh karena itu sektor pendidikan harus terus ditingkatkan mutunya. Berbagai usaha telah dilakukan untuk meningkatkan mutu pendidikan, salah satunya dengan memanfaatkan teknologi informasi dan komunikasi dalam aktivitas pendidikan. Perkembangan teknologi informasi dan komunikasi (TIK) saat ini telah banyak memberikan kontribusi yang signifikan dalam penyebaran informasi, khususnya penyebaran informasi pendidikan.

Aziz R. (2013) memberi perumpamaan yang sangat baik dalam menghadapi perkembangan TIK. Dia mengatakan, "apabila TIK tersebut diibaratkan arus badai, maka setidak-tidaknya ada tiga kemungkinan sikap kita menghadapinya, yaitu mencoba bertahan melawan arus, hanyut terbawa arus, atau memanfaatkan

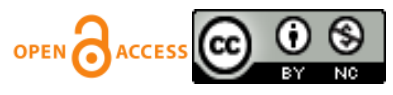


https://jurnal.unsulbar.ac.id/index.php/saintifik

arus $^{\text {ee }}$. Dalam perumpamaan ini, sikap yang paling tepat adalah yang terakhir, memanfaatkan arus sebagai sumber energi. Demikian pula dalam dunia pendidikan, arus TIK telah masuk ke dunia pendidikan. Hadirnya TIK di sekolah, di ruang kelas, di rumah, bahkan di kamar tidur siswa, tidak lagi dapat dibendung. Hadirnya TIK bukan lagi sebuah pilihan, kita memilih ataupun tidak, era TIK telah hadir.

Secara geografis, sosial dan ekonomis, penerapan dan pengembangan teknologi informasi dan komunikasi akan menjadi tulang punggung sistem pendidikan Indonesia di masa depan. Teknologi informasi dan komunikasi yang akan dikembangkan tersebut harus mampu mengangkat harkat dan nilai kemanusiaan dengan terciptanya layanan pendidikan yang lebih bermutu dan efisien. Kondisi tersebut dapat memenuhi kebutuhan manusia di era globalisasi dan kompetitif ini. Teknologi informasi dan komunikasi yang berkembang sekarang ini telah memberikan pengaruh terhadap proses pembelajaran.

Perubahan yang terjadi dalam proses pembelajaran, yaitu pembelajaran yang biasanya dilakukan terbatas di ruang kelas dan jadwal yang telah ditentukan, berkembang menjadi pembelajaran jarak jauh yang bisa dilaksanakan di manapun dan kapanpun. Pembelajaran yang biasanya melibatkan fasilitas berupa materi atau fisik seperti buku, saat ini berkembang dengan memanfaatkan fasilitas jaringan kerja (network) dengan memanfaatkan teknologi komputer dengan internetnya, sehingga terbentuk pembelajaran "online". Dengan adanya pembelajaran secara online ini, maka keterbatasan geografis, sosial dan ekonomis tidak lagi menjadi penghalang bagi siapapun yang berminat untuk belajar.

TIK mempunyai potensi yang sangat besar untuk dimanfaatkan dalam dunia pendidikan. Pada blue print TIK Depdiknas, setidak-tidaknya disebutkan ada tujuh fungsi TIK dalam pendidikan, yakni sebagai sumber belajar, alat bantu belajar, fasilitas pembelajaran, standar kompetensi, sistem administrasi, pendukung keputusan, dan sebagai infrastruktur.

Akibat dari pemanfaatan TIK dalam pendidikan itulah akhirnya dikembangkan suatu pembelajaran yang menggunakan media e-learning. Arizona (2013) dalam jurnal Penerapan Perangkat Pembelajaran Sains Berbasis CTL dan E-Learning menjelaskan bahwa e-learning merupakan sebuah proses pembelajaran yang berbasis elektronika. Salah satu media yang digunakan adalah jaringan komputer. Dengan dikembangkannya di jaringan komputer memungkinkan untuk dikembangkan dalam bentuk berbasis web, sehingga kemudian dikembangkan ke jaringan komputer yang lebih luas yaitu internet. Penyajian $e$ learning berbasis web ini bisa menjadi lebih interaktif. Materi pengajaran dan pembelajaran yang disampaikan melalui media ini berbentuk teks, grafik, animasi, simulasi, audio dan video, serta ruang diskusi yang memudahkan siswa untuk berinteraktif dengan guru. Perbedaan pembelajaran tradisional dengan e-learning yaitu pada kelas tradisional, guru dianggap sebagai orang yang serba tahu dan ditugaskan untuk menyalurkan ilmu pengetahuan kepada pelajarnya. Sedangkan di dalam pembelajaran e-learning fokus utamanya adalah pelajar. Pelajar mandiri pada waktu tertentu dan bertanggung-jawab untuk pembelajarannya. Suasana pembelajaran e-learning akan memaksa pelajar memainkan peranan yang lebih aktif dalam pembelajarannya. Pelajar membuat perancangan dan mencari materi dengan usaha, dan inisiatif sendiri.

Kemudian Cisco dalam Dodon (2013) mendefinisikan filosofis e-Learning sebagai berikut. $e$ Learning merupakan penyampaian informasi, komunikasi, pendidikan, pelatihan secara online. e-Learning menyediakan seperangkat alat yang dapat memperkaya nilai belajar secara konvensional (model belajar konvensional, kajian terhadap buku teks, CD-ROM, dan pelatihan berbasis komputer) sehingga dapat menjawab tantangan perkembangan globalisasi. e-Learning tidak berarti menggantikan model belajar konvensional di dalam kelas, tetapi memperkuat model belajar tersebut melalui pengayaan content dan pengembangan teknologi pendidikan.

Berdasarkan definisi dan filosofi diatas, dapat dijelaskan bahwa secara prinsip, e-Learning dapat diartikan sebagai pembelajaran yang menggunakan media elektronik sebagai alat bantunya, media elektronik tersebut dapat saja berupa internet, TV, CD ROM, Radio, Teleconference, dan lain sebagainya. Konsep e-Learning harus mengadaptasi unsur-unsur yang biasa dilakukan dalam sistem pembelajaran konvensional.

Zhang D. (2005) dalam penelitiannya membuktikan siswa dalam lingkungan e-learning mencapai kinerja pembelajaran secara signifikan lebih baik dan tingkat kepuasan belajar lebih tinggi dibandingkan dengan siswa yang belajar secara tradisional. 
https://jurnal.unsulbar.ac.id/index.php/saintifik

Dalam perkembangannya, e-learning juga menambahkan konten simulasi interaktif berbasis laboratorium virtual khususnya bagi e-learning untuk mata pelajaran IPA. Prakash A. Bhadane (2013) dalam jurnalnya yang berjudul Interfacing of Java 3D Objects for Virtual Physics Lab (VP Lab) Setup for Encouraging Physics Studies menjelaskan bahwa pembelajaran berbasis simulasi dalam lingkungan virtual 3D telah menciptakan teknologi yang dapat diakses luas dan telah secara dramatis mengurangi harga dari perangkat keras wajib.

Berdasarkan hasil wawancara dan observasi awal di SMP Negeri 4 Kendari pada bulan Januari 2014 pada guru IPA kelas VII, ditemukan kenyataan bahwa proses pembelajaran IPA masih dilaksanakan dengan model pembelajaran konvensional. Dalam model pembelajaran ini selalu terpusatkan oleh guru sehingga untuk memahami pelajaran yang dibawakan sang guru, siswa harus hadir dalam proses pelajaran tersebut. Sekarang bagaimana dengan siswa yang sakit, izin atau tidak sempat hadir dengan alasan yang lainnya pada proses belajar mengajar? Pasti mereka akan mengalami keterlambatan dan susah memahami konsep yang akan diajarkan selanjutnya. Hal ini tentu saja akan berimbas pada hasil belajar mereka.

Berdasarkan semua penjelasan diatas, peneliti ingin mencari solusi dalam rangka meningkatkan kualitas pembelajaran di sekolah, dan juga menyediakan wadah pembelajaran alternatif bagi siswa yang dapat digunakan kapan saja dan di mana saja, dengan tujuan untuk meningkatkan hasil belajar siswa pada mata pelajaran IPA dengan cara memanfaatkan pembelajaran dalam format $e$-learning.

\section{METODE PENELITIAN}

Penelitian ini merupakan penelitian eksperimen menggunakan desain Pretest-posttest Control Group Design. Terdapat dua kelompok/kelas sampel dalam desain ini, yaitu kelas eksperimen dan kelas kontrol. Penetapan kelas sampel dilakukan secara acak.

Penelitian ini dilaksanakan pada bulan Maret semester genap tahun pelajaran 2013/2014 di SMP Negeri 4 Kendari. Populasi dalam penelitian ini adalah seluruh siswa kelas VII SMP Negeri 4 Kendari sebanyak 399 orang yang terdistribusi dalam 10 kelas. Setelah pengambilan sampel secara acak, maka ditentukan kelas VII 5 sebagai kelas eksperimen dan kelas VII 6 sebagai kelas kontrol.

Variabel bebas dalam penelitian ini adalah penggunaan media pembelajaran e-learning berbasis web online di kelas eksperimen dan model pembelajaran konvensional di kelas kontrol. Kemudian variabel terikatnya adalah hasil belajar IPA siswa.

Instrumen yang digunakan dalam penelitian ini adalah lembar observasi dan tes hasil belajar. Lembar observasi digunakan untuk mengamati aktivitas yang terjadi dalam proses pembelajaran dengan menggunakan media pembelajaran e-learning berbasis web online berlangsung, dalam hal ini aktivitas yang diamati adalah aktivitas guru dan aktivitas siswa. Lembar observasi terhadap aktivitas guru dan aktivitas siswa ini difokuskan pada keterlaksanaan pembelajaran dengan menggunakan media pembelajaran $e$ learning berbasis web online. Kemudian tes hasil belajar dikonstruksi dalam bentuk tes objektif model pilihan ganda dengan jumlah pilihan sebanyak empat yang berjumlah 50 butir soal yang disusun berdasarkan tujuan pembelajaran dengan tingkat kognitif yaitu $\mathrm{C} 1, \mathrm{C} 2, \mathrm{C} 3$ dan $\mathrm{C} 4$ dan pilihan skor, jika jawaban benar diberi skor 1 dan jika jawaban salah diberi skor 0. Setiap soal dibuat untuk menguji pemahaman siswa terhadap konsep-konsep yang tercakup dalam materi pokok suhu dan perubahannya, tes ini bersifat konseptual. Setelah divalidasi, jumlah soal yang digunakan yaitu 35 butir soal. Tes ini dilakukan dua kali, yaitu pada saat pre-test sebelum materi pokok suhu dan perubahannya diajarkan dan pada saat post-test setelah materi pokok suhu dan perubahannya selesai dilaksanakan.

Teknik analisis data yang dilakukan menggunakan teknik statistik, yaitu statistik deskriptif dan statistik inferensial. Statistik deskriptif digunakan untuk mendeskripsikan nilai yang diperoleh masingmasing kelas dalam bentuk skor hasil belajar, skor rata-rata, standar deviasi, klasifikasi skor hasil belajar dan peningkatan hasil belajar (gain). statistik inferensial dimaksudkan untuk menguji hipotesis penelitian. Sebelum pengujian hipotesis, maka terlebih dahulu dilakukan pengujian dasar-dasar analisis sebagai pedoman untuk melakukan uji mana yang akan dipakai. Adapun pengujian dasar-dasar analisis yang digunakan terdiri atas pengujian normalitas data dan homogenitas data. Pengujian hipotesis dengan menggunakan uji-t pada tingkat kesalahan $\alpha=0,05$. 


\section{HASIL DAN PEMBAHASAN}

Dalam penelitian ini dideskripsikan data tentang pre-test dan post-test hasil belajar siswa, baik siswa kelas eksperimen maupun siswa kelas kontrol. Selain itu, dalam penelitian ini juga dideskripsikan tentang gain atau peningkatan hasil belajar siswa, baik siswa kelas eksperimen maupun siswa kelas kontrol.

Tabel 1. Deskripsi Hasil Belajar Siswa Kelas Eksperimen dan Kelas Kontrol

\begin{tabular}{|c|c|c|c|c|c|c|}
\hline \multirow{2}{*}{ Skor } & \multicolumn{3}{|c|}{ Kelas Eksperimen } & \multicolumn{3}{c|}{ Kelas Kontrol } \\
\cline { 2 - 7 } & Pre-test & Post-test & Gain & Pre-test & Post-test & Gain \\
\hline Maksimum & 43 & 86 & 0,73 & 40 & 63 & 0,42 \\
\hline Minimum & 14 & 51 & 0,26 & 17 & 40 & 0,14 \\
\hline Rata-rata $(\bar{X})$ & 24,7 & 62,86 & 0,50 & 27,64 & 50,29 & 0,31 \\
\hline $\begin{array}{c}\text { Standar Deviasi } \\
(\text { SD) }\end{array}$ & 6,89 & 7,18 & 0,10 & 6,15 & 5,89 & 0,08 \\
\hline
\end{tabular}

Dari Tabel 1. secara umum dapat dilihat bahwa gambaran hasil pre-test siswa kelas eksperimen dan siswa kelas kontrol tidak jauh berbeda. Sedangkan gambaran hasil post-test siswa dapat dilihat dari skor rata-rata hasil post-test baik kelas eksperimen maupun kelas kontrol sama-sama mengalami peningkatan, namun peningkatan skor rata-rata hasil post-test siswa kelas eksperimen lebih tinggi dibandingkan dengan skor rata-rata hasil post-test siswa kelas kontrol.

Pengkategorian data hasil belajar pre-test siswa kelas eksperimen dan kelas kontrol untuk lebih jelasnya dapat dilihat pada Gambar 1. dan 2.

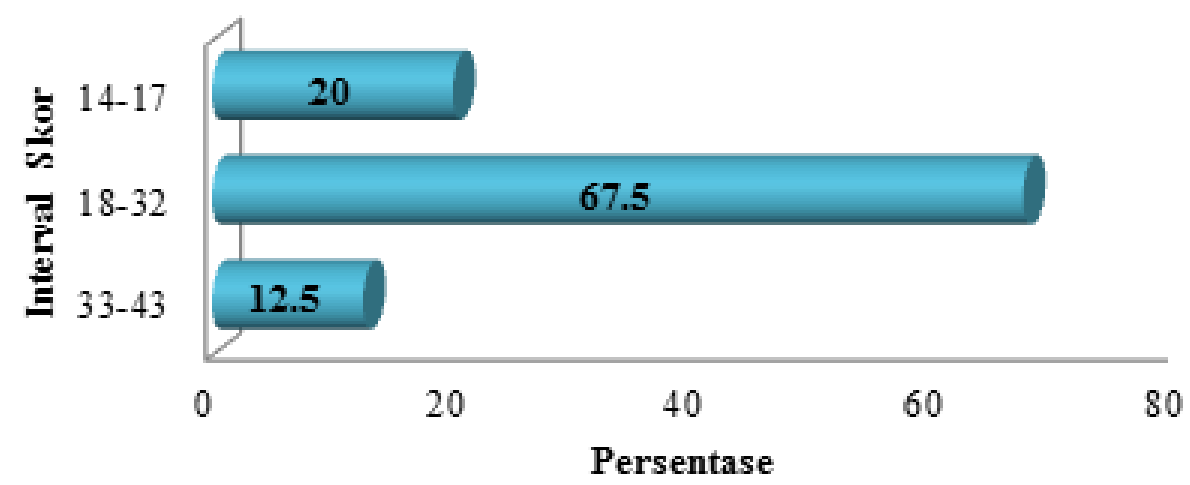

Gambar 1. Grafik Kategori Hasil Belajar Pretest Siswa Kelas Eksperimen 


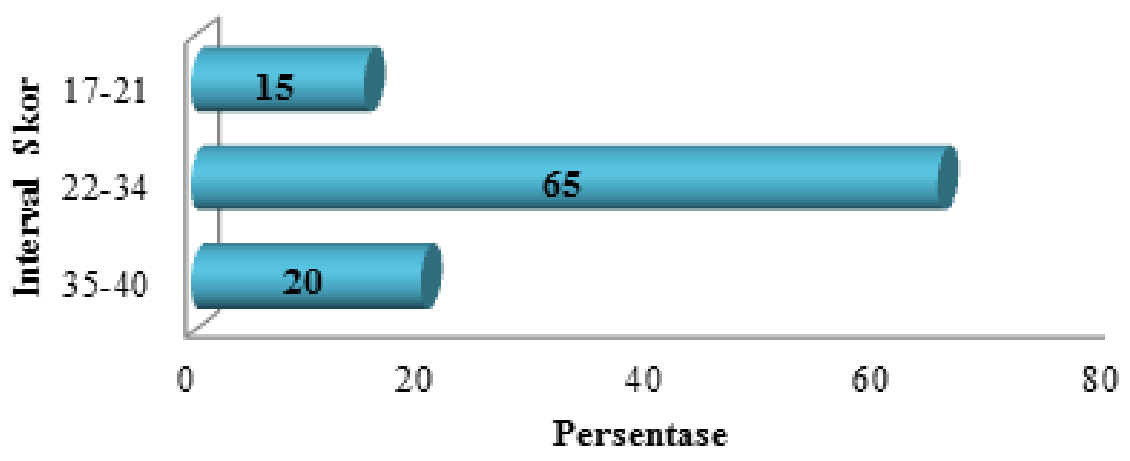

Gambar 2. Grafik Kategori Hasil Belajar Pretest Siswa Kelas Kontrol

Berdasarkan Gambar 1. dan 2. secara umum maka dapat dikatakan bahwa gambaran hasil belajar pretest siswa kelas eksperimen sebagian besar siswa memperoleh skor dengan kategori sedang sama halnya dengan kelas kontrol dimana pada kelas eksperimen sebesar $67,5 \%$ dan $65 \%$ pada kelas kontrol.

Adapun pengkategorian hasil belajar post-test siswa kelas eksperimen dan kelas kontrol dapat disajikan pada Gambar 3. dan 4.

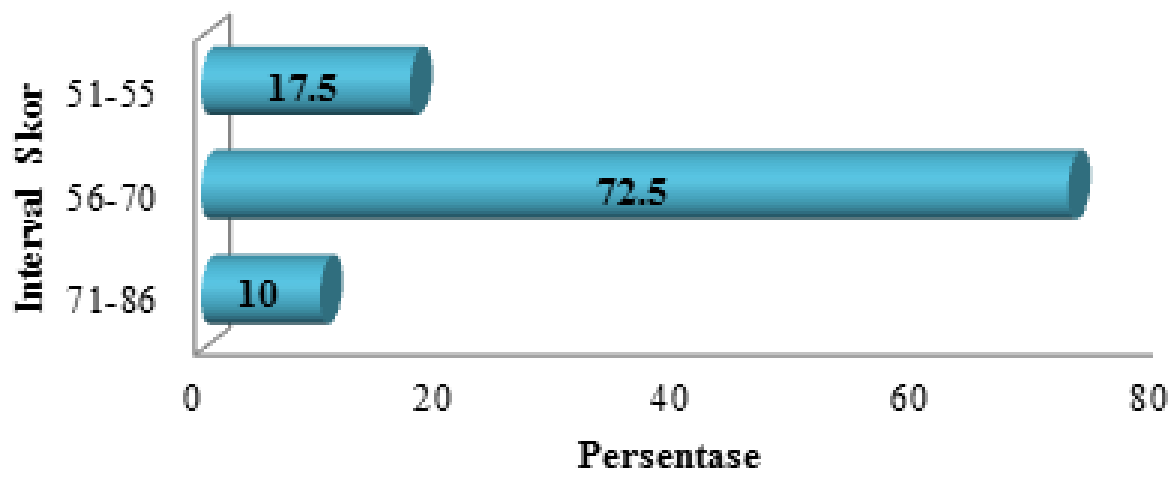

Gambar 3. Grafik Kategori Hasil Belajar Post-test Siswa Kelas Eksperimen

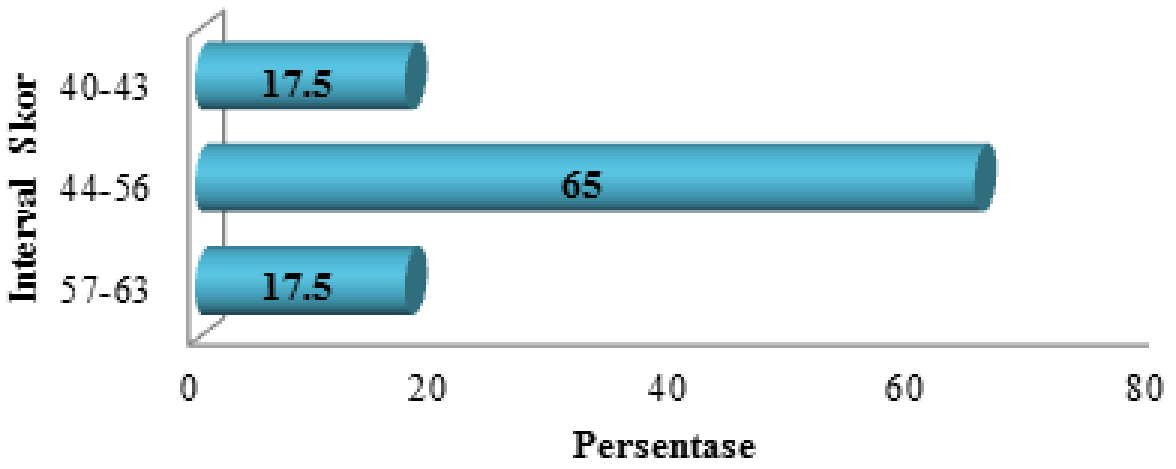

Gambar 4. Grafik Kategori Hasil Belajar Post-test Siswa Kelas Kontrol

Dari Gambar 3. dan 4. secara umum dapat dikatakan bahwa skor hasil belajar post-test siswa kelas eksperimen lebih banyak siswa yang memperoleh skor dengan kategori sedang dibandingkan dengan siswa kelas kontrol namun pada kategori tinggi siswa pada kelas kontrol lebih banyak daripada siswa kelas eksperimen, tetapi interval skor kelas eksperimen (71-86) lebih tinggi daripada interval nilai kelas kontrol (57-63). Selain itu, interval skor pada post-test mengalami peningkatan dibandingkan interval skor pada pre-test. 
Kemudian untuk melihat pengkategorian gain (peningkatan) hasil belajar siswa kelas eksperimen dan siswa kelas kontrol sesudah pembelajaran dapat dilihat pada Tabel 2.

Tabel 2. Deskripsi Gain Hasil Belajar Siswa Kelas Eksperimen dan Kelas Kontrol

\begin{tabular}{|c|c|c|c|c|c|}
\hline \multirow{3}{*}{ Interval Skor } & \multirow{3}{*}{ Kategori } & \multicolumn{4}{|c|}{ Gain } \\
\hline & & \multicolumn{2}{|c|}{ Kelas Eksperimen } & \multicolumn{2}{|c|}{ Kelas Kontrol } \\
\hline & & f & $\%$ & f & $\%$ \\
\hline $0 \leq \mathrm{g}<0,3$ & Rendah & 1 & 2,5 & 15 & 37,5 \\
\hline $0,3 \leq \mathrm{g} \leq 0,7$ & Sedang & 38 & 95 & 25 & 62,5 \\
\hline $0,7<\mathrm{g} \leq 1$ & Tinggi & 1 & 2,5 & 0 & 0 \\
\hline \multicolumn{2}{|c|}{ Jumlah } & 40 & 100 & 40 & 100 \\
\hline
\end{tabular}

Untuk lebih jelasnya deskripsi gain hasil belajar siswa kelas eksperimen dan kelas kontrol dapat dilihat pada Gambar 5.

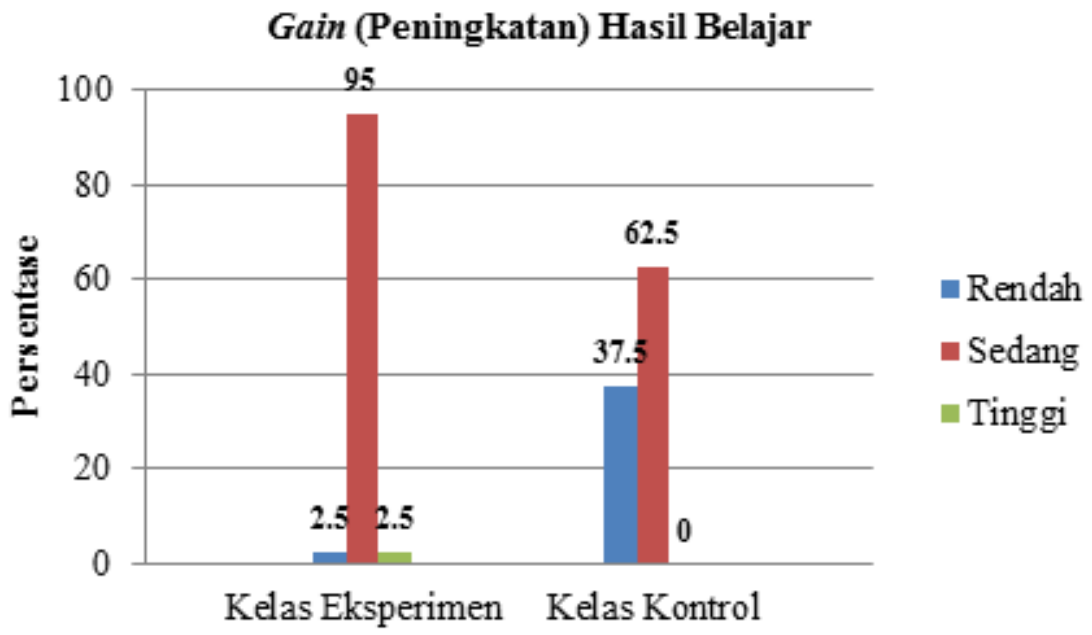

Gambar 5. Deskripsi Gain Hasil Belajar Pre-test dan Post-test Siswa Kelas Eksperimen dan Siswa Kelas Kontrol

Berdasarkan Gambar 5. secara umum dapat dilihat bahwa persentase gain (peningkatan) hasil belajar siswa kelas eksperimen lebih banyak yang mendapat skor dengan kategori sedang dibandingkan dengan skor gain (peningkatan) hasil belajar siswa kelas kontrol. Selain itu, gain (peningkatan) hasil belajar siswa kelas eksperimen terdapat siswa yang memperoleh skor dengan kategori tinggi dan persentase gain (peningkatan) hasil belajar siswa kelas eksperimen lebih sedikit siswa yang mendapat skor dengan kategori rendah dibandingkan dengan gain (peningkatan) hasil belajar siswa kelas kontrol.

Hasil uji normalitas data hasil belajar Fisika siswa kelas eksperimen dan siswa kelas kontrol lebih jelas disajikan pada Tabel 3. 
https://jurnal.unsulbar.ac.id/index.php/saintifik

Tabel 3. Hasil Uji Normalitas Data Hasil Belajar Siswa Kelas Eksperimen dan Kelas Kontrol

Keterangan: *) $\alpha=0,05$

\begin{tabular}{|c|c|c|c|c|}
\hline \multirow{2}{*}{ Kelas } & $\begin{array}{c}\text { Aspek yang } \\
\text { Diuji }\end{array}$ & $\chi_{\text {hit }}^{2}$ & $\chi_{\text {tab }}^{2}$ & Keterangan \\
\hline \multirow{3}{*}{ Eksperimen } & Pre-test & 4,60 & 7,81 & Normal *) \\
\cline { 2 - 5 } & Post-test & 4,32 & 7,81 & Normal *) \\
\cline { 2 - 5 } Kontrol & Gain & 2,85 & 7,81 & Normal *) \\
\hline \multirow{3}{*}{} & Pre-test & 5,61 & 7,81 & Normal *) \\
\cline { 2 - 5 } & Post-test & 4,32 & 7,81 & Normal *) \\
\cline { 2 - 5 } & Gain & 6,55 & 7,81 & Normal *) \\
\hline
\end{tabular}

Hasil uji homogenitas varians data hasil belajar IPA-Fisika siswa kelas eksperimen dan siswa kelas kontrol singkatnya disajikan pada Tabel 4.

Tabel 4. Hasil Uji Homogenitas Varians Data Hasil Belajar Siswa Kelas Eksperimen dan Kelas Kontrol

\begin{tabular}{|c|c|c|c|c|c|}
\hline $\begin{array}{c}\text { Data yang } \\
\text { Diuji }\end{array}$ & $\begin{array}{c}\text { Varians } \\
\text { Terbesar } \\
\left(\mathrm{S}_{1}{ }^{2}\right)\end{array}$ & $\begin{array}{c}\text { Varians } \\
\text { Terkecil } \\
\left(\mathrm{S}_{2}{ }^{2}\right)\end{array}$ & $F_{\text {hit }}$ & $F_{\text {tab }}$ & Keterangan \\
\hline Pre-test & 47,47 & 34,69 & 1,37 & 1,69 & Homogen *) \\
\hline Post-test & 51,55 & 37,82 & 1,36 & 1,69 & Homogen *) \\
\hline Gain & 0,01 & 0,0064 & 1,56 & 1,69 & Homogen *) \\
\hline
\end{tabular}

Keterangan: *) $\alpha=0,05$

Hasil dari pengujian hipotesis dengan menggunakan uji-t adalah sebagai berikut:

1) Pengujian Hipotesis 1

Hasil uji beda rata-rata data pre-test siswa kelas eksperimen dan data pre-test siswa kelas kontrol diperoleh skor $t_{\text {hit }}=-1,96$ dan skor $t_{\text {tab }}$ dengan uji dua pihak pada taraf $\alpha=0,05$ serta $d k=78$ sebesar 1,98 Karena berlaku hubungan $-t_{1-\frac{1}{2} \alpha}<t_{h i t}<t_{1-\frac{1}{2} \alpha}$, yaitu $-1,98<-1,96<1,98$ maka dapat disimpulkan $\mathrm{H}_{0}$ diterima, artinya tidak ada perbedaan yang signifikan antara skor rata-rata pretest hasil belajar siswa kelas eksperimen dengan skor rata-rata pre-test hasil belajar siswa kelas kontrol.

2) Pengujian Hipotesis 2

Hasil uji beda rata-rata data post-test siswa kelas eksperimen dan data post-test siswa kelas kontrol diperoleh skor $t_{\text {hit }}=8,12$ dan skor $t_{\text {tab }}$ dengan uji satu pihak pada taraf $\alpha=0,05$ serta $d k=78$ sebesar 1,98. Karena berlaku hubungan $t_{\text {hit }}>t_{1-\alpha}$, yaitu 8,12 $>1,98$ maka dapat disimpulkan $\mathrm{H}_{0}$ ditolak, artinya rata-rata hasil belajar (post-test) siswa kelas eksperimen lebih baik secara signifikan daripada rata-rata hasil belajar (post-test) siswa kelas kontrol. 
3) Pengujian Hipotesis 3

Hasil uji beda rata-rata data gain siswa kelas eksperimen dan data gain siswa kelas kontrol diperoleh skor $t_{\text {hit }}=9,17$ dan skor $t_{\text {tab }}$ dengan uji satu pihak pada taraf $\alpha=0,05$ serta $d k=78$ sebesar 1,98 . Karena berlaku hubungan $t_{h i t}>t_{1-\alpha}$, yaitu 9,17>1,98 maka dapat disimpulkan $\mathrm{H}_{0}$ ditolak, artinya ratarata data gain hasil belajar siswa kelas eksperimen lebih baik secara signifikan daripada rata-rata data gain hasil belajar siswa kelas kontrol.

Tabel 5. Hasil Uji Hipotesis Data Hasil Belajar Siswa Kelas Eksperimen dan Kelas Kontrol

\begin{tabular}{|c|c|c|c|}
\hline Data Yang Diuji & $\mathbf{t}_{\text {hit }}$ & $\mathbf{t}_{\text {tab }}$ & Keterangan \\
\hline Pre-test & $-1,96$ & 1,98 & $\mathrm{H}_{0}$ Diterima *) \\
\hline Post-test & 8,12 & 1,98 & $\mathrm{H}_{0}$ Ditolak *) \\
\hline Gain & 9,17 & 1,98 & $\mathrm{H}_{0}$ Ditolak $\left.*\right)$ \\
\hline
\end{tabular}

Keterangan: *) $\alpha=0,05$

\section{HASIL DAN PEMBAHASAN}

Berdasarkan hasil analisis data penelitian dan pengujian hipotesis terdapat bahwa hasil belajar IPA siswa kelas eksperimen yang menggunakan media pembelajaran $e$-Learning berbasis web online lebih baik secara signifikan dibandingkan dengan hasil belajar IPA siswa kelas kontrol yang menggunakan model pembelajaran konvensional.

Untuk mengetahui kejelasan persepsi tersebut, maka pada awal pembelajaran dilakukan pre-test dan di akhir pembelajaran dilakukan post-test. Pre-test dilakukan dengan tujuan untuk mengetahui kemampuan awal siswa kelas eksperimen dan kelas kontrol terhadap materi yang akan diajarkan atau sebelum pembelajaran dilaksanakan. Dan post-test dilakukan dengan tujuan untuk mengetahui kemampuan akhir siswa kelas eksperimen dan kelas kontrol setelah materi diajarkan atau setelah pembelajaran dilaksanakan.

Jika dilihat dari hasil pre-test siswa sebelum pembelajaran dimulai, sebagian besar nilai hasil pretest siswa baik kelas eksperimen maupun kelas kontrol termasuk ke dalam kategori sedang dan ada beberapa siswa memperoleh nilai dengan kategori tinggi dan rendah. Namun jika melihat skor rata-rata hasil pre-test siswa kelas eksperimen dan kelas kontrol setelah dilakukan analisis inverensial menggunakan uji-t, menunjukkan bahwa hasil pre-test kedua kelas tidak ada perbedaan secara signifikan. Hal ini disebabkan karena siswa baik kelas eksperimen maupun kelas kontrol memiliki tingkat kemampuan yang relatif sama sebelum pembelajaran. Selain itu, kedua kelas belum mendapatkan materi tentang suhu dan perubahannya tersebut secara detail sehingga pemahaman dan pengetahuan mereka masih sangat terbatas dan belum diberikan perlakuan di dalam kelas.

Pembelajaran dilaksanakan sebanyak 3 kali pertemuan pada tiap-tiap kelas setelah dilaksanakan pretest. Pertemuan awal untuk kelas eksperimen yang menggunakan media pembelajaran $e$-Learning berbasis web untuk sub pokok suhu dan termometer. Sistem media yang digunakan adalah web centric course dan model pembelajaran blended learning dimana akan ada kolaborasi antara pembelajaran secara tradisional dan pembelajaran online. Web e-Learning diakses dengan mengunjungi alamat http://ikballearning.phpnet.us. Adapun tampilannya dapat dilihat pada Gambar 6. dan Gambar 7. 


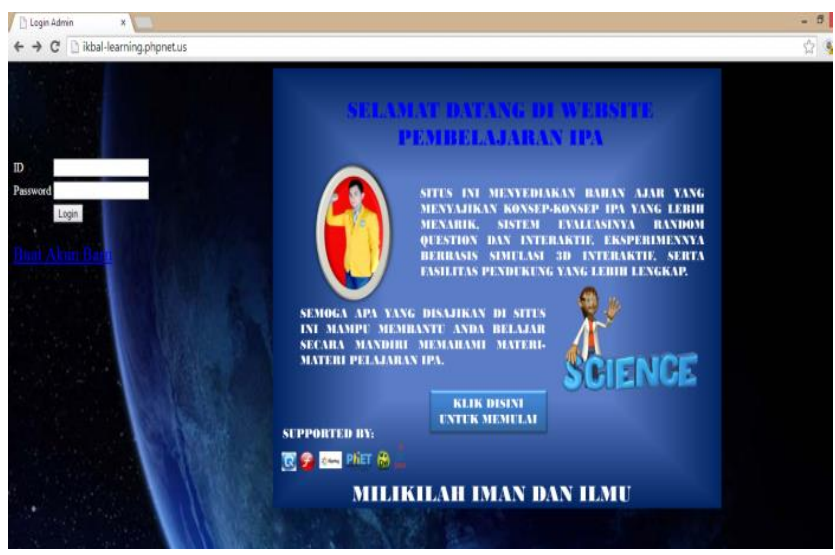

Gambar 6. Halaman Awal Web e-Learning

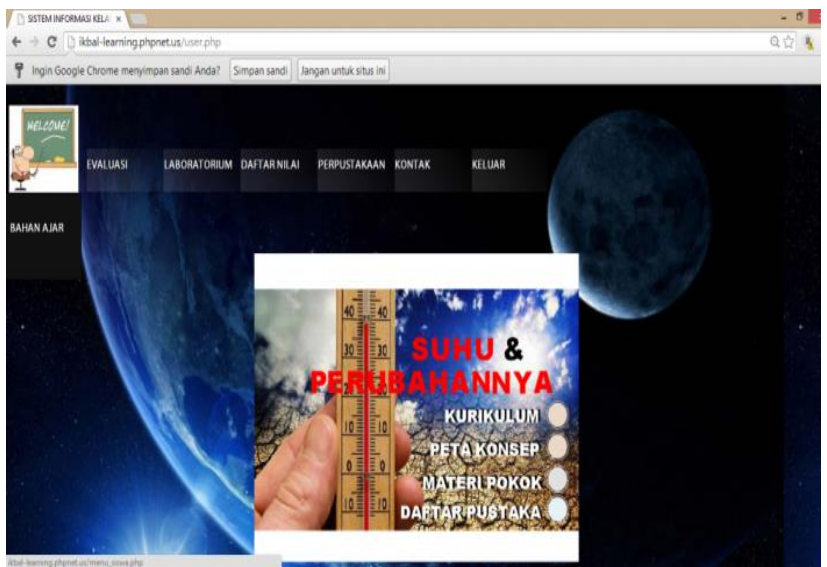

Gambar 7. Halaman Materi Pelajaran

Sesi pertama yaitu sesi live synchronous dimana pembelajaran dilaksanakan di laboratorium secara langsung. Sesi kedua virtual synchronous dimana siswa diberi kesempatan untuk bertanya pada kolom komentar yang tersedia di web e-learning mengenai konsep yang tidak dimengerti. Kemudian pada sesi ketiga yaitu self-paced asynchronous dimana siswa diberikan waktu untuk memperdalam materi yang telah diajarkan secara mandiri. Kemudian pada tahap terakhir yaitu collaborative asynchronous siswa melakukan eksperimen virtual dengan menggunakan Phet Interactive Simulations yang dibagi dalam beberapa kelompok. Eksperimen virtual adalah kegiatan eksperimen siswa dengan menggunakan simulasi virtual yang suasananya seperti melakukan eksperimen secara langsung. Eksperimen virtual berfungsi sebagai ajang latihan, analisis dan lain-lain sebelum melakukan eksperimen secara langsung dengan tujuan untuk menekan terjadinya kesalahan kerja ketika melaksanakan eksperimen secara langsung. Pada penelitian ini tidak dilakukan eksperimen secara langsung karena penelitian ini berfokus pada pembelajaran secara virtual.

Pada pertemuan pertama ini terlihat bahwa rata-rata aktivitas siswa untuk semua kelompok adalah sebesar 2,75 yang berada pada kategori cukup. Hal ini terlihat dari perilaku siswa pada proses pengerjaan lembar kerja siswa masih terdapat 2-3 siswa yang tidak aktif dalam berpikir bersama untuk menyelesaikan tugas atau pertanyaan yang diberikan guru dalam bentuk lembar kerja siswa karena siswa cenderung terbiasa bekerja dengan teman-teman dekatnya dan tidak mau bekerja sama dengan teman yang dianggap malas, nakal dan hal yang lainnya. Selain itu, setiap kelompok masih belum menyelesaikan lembar kerja siswa sesuai dengan waktu yang diberikan, sehingga saat guru memanggil perwakilan kelompok tertentu untuk mempresentasikan hasil kerja kelompoknya di depan kelas hanya siswa dari kelompok yang telah selesai yang dipanggil dan dalam menanggapi jawaban anggota dari kelompok lain hanya sedikit kelompok 
https://jurnal.unsulbar.ac.id/index.php/saintifik

yang melakukannya karena sebagian besar siswa sibuk bermain-main dengan simulasi yang disediakan dan ada juga yang berteriak "lanjut saja pak" hal ini dikarenakan proses praktikum dilaksanakan sore hari karena pada saat jam sekolah jaringan internet dimatikan oleh pengelola laboratorium komputer karena situasi sedang hujan deras disertai bunyi petir.

Kemudian, untuk pertemuan selanjutnya yakni pertemuan kedua dan pertemuan terakhir, rata-rata aktivitas siswa secara keseluruhan telah meningkat yaitu pada pertemuan kedua rata-rata aktivitas siswa sebesar 3,5 dan pertemuan terakhir sebesar 3,65 serta kedua pertemuan ini termasuk dalam kategori baik. Hal ini terlihat ketika guru memberikan penjelasan mengenai materi yang didemonstrasikan melalui web e-Learning beberapa siswa antusias dalam bertanya berkaitan dengan materi. Dalam diskusi atau kegiatan kelompok lainnya siswa sudah mulai aktif dalam berpikir bersama dan antusias dalam memberikan jawaban dari pertanyaan-pertanyaan yang diajukan.

Setelah pembelajaran materi pokok suhu dan perubahannya selesai, hasil belajar baik siswa kelas eksperimen maupun kelas kontrol mengalami peningkatan atau dapat dikatakan terjadi kemajuan hasil belajar. Hail belajar merupakan kemampuan yang dimiliki siswa setelah mengalami proses belajar atau dapat dikatakan sebagai ukuran keberhasilan siswa dalam memahami materi yang telah diberikan.

Hal ini dapat dilihat dari skor rata-rata hasil post-test lebih baik dari skor rata-rata hasil pre-test siswa. Dimana, hasil post-test pada kelas eksperimen diperoleh rata-rata skor sebesar 62,86 dan standar deviasi 7,18, sedangkan hasil post-test kelas kontrol diperoleh rata-rata skor sebesar 50,29 dan standar deviasi 5,89. Dari hasil post-test tersebut terlihat bahwa standar deviasi kelas eksperimen lebih besar dari kelas kontrol karena sebaran data hasil post-test siswa kelas eksperimen sangat bervariasi. Selain itu, jika dilihat dari skor rata-rata dari kedua kelas perbedaannya cukup jauh, hal ini diperkuat dengan hasil pengujian hipotesis menunjukkan bahwa rata-rata post-test siswa kelas eksperimen lebih baik daripada rata-rata post-test siswa kelas kontrol. Hanya saja yang diperoleh belum sesuai harapan (sedikit siswa yang lebih dari KKM 70) karena pada saat proses pembelajaran berlangsung hampir sebagian besar siswa memiliki kemampuan dasar matematika masih kurang dan sebagian besar pula siswa tidak mempersiapkan diri dalam hal ini belajar karena bertepatan dengan beberapa ulangan pada pelajaran lain.

Jika dilihat dari gain (peningkatan) hasil belajar IPA siswa kelas eksperimen dan kelas kontrol pada materi pokok suhu dan termometer terdapat perbedaan. Gain (peningkatan) hasil belajar IPA siswa kelas eksperimen lebih besar dari kelas kontrol. Hal ini ditunjukkan dengan rata-rata gain (peningkatan) hasil belajar IPA siswa kelas eksperimen yaitu sebesar 0,5 sedangkan gain (peningkatan) siswa kelas kontrol yaitu sebesar 0,31. Hasil ini dipertegas dengan pengujian secara inferensial pada hipotesis ketiga, yang mana diperoleh kesimpulan bahwa rata-rata gain (peningkatan) hasil belajar IPA siswa kelas eksperimen lebih baik secara signifikan daripada rata-rata gain (peningkatan) hasil belajar IPA siswa kelas kontrol.

Secara deskriptif hasil belajar IPA untuk siswa kelas eksperimen setelah pembelajaran masih juga terdapat siswa yang memperoleh nilai dengan kategori rendah, namun interval nilai yang digunakan lebih meningkat dari sebelum pembelajaran dilaksanakan dan sebagian besar siswa memperoleh skor dengan kategori sedang serta beberapa siswa juga memperoleh skor dengan kategori tinggi. Sedangkan, untuk kelas kontrol hasil belajar setelah pembelajaran dilaksanakan masih terdapat siswa yang memperoleh skor dengan kategori rendah yang sama dengan siswa kelas eksperimen.

Selain itu, beberapa siswa dari kelas kontrol memperoleh skor dengan kategori sedang dan tinggi, namun persentase skor hasil belajar kelas kontrol lebih rendah dari persentase skor hasil belajar kelas eksperimen dan interval skor yang digunakan pada kelas kontrol pula lebih rendah dari kelas eksperimen. Masih terdapat siswa yang memperoleh skor dengan kategori rendah baik kelas eksperimen maupun kelas kontrol sebab masih kurangnya pemahaman siswa.

Perbedaan hasil belajar IPA siswa kelas eksperimen dan kelas kontrol diduga akibat adanya perlakuan yang berbeda dalam proses pembelajaran yaitu untuk kelas eksperimen menggunakan media pembelajaran e-Learning berbasis web online, sedangkan untuk kelas kontrol menggunakan model pembelajaran konvensional yang biasa dilakukan oleh guru sebelumnya. Hal yang paling membedakan antara kelas eksperimen dan kelas kontrol yaitu pada kelas eksperimen penyajian materinya dilakukan dengan membuka web e-Learning sehingga siswa dapat memperoleh pengalaman menarik, tambahan informasi dan pengetahuan. Siswa mempelajari bukan hanya dari apa yang di baca dan di dengar, namun 
https://jurnal.unsulbar.ac.id/index.php/saintifik

lebih jauh lagi, siswa belajar pula dari apa yang dilihat, dialami, dibuat atau dikerjakan. Proses tersebut memungkinkan seluruh potensi siswa berperan secara optimal dalam memahami dan bahkan menemukan informasi baru. Selain itu, dengan menggunakan media pembelajaran e-Learning berbasis web online memungkinkan adanya interaksi multi arah yang terjadi sehingga siswa tidak terkesan pasif di kelas dan siswa lebih cepat memahami materi yang menyebabkan aktivitas siswa di dalam kelas meningkat. Hal ini sejalan dengan Zhang D. (2005) dimana sebelumnya dalam penelitian membuktikan siswa dalam lingkungan e-learning mencapai kinerja pembelajaran secara signifikan lebih baik dan tingkat kepuasan belajar lebih tinggi dibandingkan dengan siswa yang belajar secara tradisional/konvensional.

Berbeda halnya dengan proses pembelajaran pada kelas kontrol yang menggunakan model pembelajaran konvensional. Dimana, proses pembelajaran dilaksanakan dengan metode ceramah. Guru memberikan penjelasan mengenai rumus-rumus yang dipelajari secara teoritis, kemudian memberikan tugas-tugas dalam bentuk latihan mengerjakan soal, maupun pekerjaan rumah. Selain itu, dalam metode ceramah ini guru lebih dominan dari pada siswa, tidak adanya interaksi antara siswa, tidak digunakan media, sehingga mengakibatkan siswa banyak yang terlihat pasif di kelas dan lebih memilih bercerita dengan teman sebangkunya.

Berdasarkan uraian tersebut terlihat bahwa dengan menggunakan media pembelajaran $e$-Learning berbasis web online dalam proses pembelajaran dapat memberikan perbedaan hasil belajar IPA siswa dengan menggunakan model pembelajaran konvensional.

Dari penelitian ini menunjukkan bahwa penggunaan media pembelajaran $e$-Learning berbasis web online harus dapat dioptimalkan dalam upaya meningkatkan hasil belajar siswa. Hal ini dapat dilihat dari pengisian angket tanggapan siswa terhadap penggunaan media pembelajaran e-Learning berbasis web online pada materi pokok suhu dan perubahannya yaitu sebagian besar siswa setuju dengan menggunakan media pembelajaran e-Learning berbasis web online dalam proses pembelajaran karena dapat memudahkan siswa dalam menguasai materi serta dapat meningkatkan motivasi dan semangat siswa dalam mengerjakan tugas yang diberikan. Selain itu, penggunaan media pembelajaran $e$-Learning berbasis web online ini juga memiliki kelemahan yang sifatnya teknis yaitu tidak adanya fasilitas absen untuk membuktikan siswa telah membuka web e-Learning dan non teknis yaitu ada siswa yang merasa terkuras dari segi ekonomi karena belajar terus di warnet. Menanggapi komentar tersebut adalah karena di Provinsi Sulawesi Tenggara layanan internet masih dikatakan sesuatu yang mahal dan masyarakat yang mempunyai fasilitas komputer rumahan dengan jaringan internetnya masih sangat kurang.

\section{KESIMPULAN}

Berdasarkan hasil penelitian, dapat disimpulkan bahwa: (1) gambaran hasil pre-test siswa kelas eksperimen pada materi pokok suhu dan perubahannya yaitu diperoleh skor maksimum 43, skor minimum 14, skor rata-rata 24,7 dan standar deviasi 6,89, sedangkan pada kelas kontrol yaitu diperoleh skor maksimum 40, skor minimum 17, skor rata-rata 27,64 dan standar deviasi 6,15, (2) gambaran hasil posttest siswa kelas eksperimen pada materi pokok suhu dan perubahannya yaitu diperoleh skor maksimum 86 , skor minimum 51, skor rata-rata 62,86 dan standar deviasi 7,18, sedangkan pada kelas kontrol yaitu diperoleh skor maksimum 63, skor minimum 40, skor rata-rata 50,29 dan standar deviasi 5,89, (3) tidak ada perbedaan yang signifikan antara skor rata-rata hasil pre-test siswa kelas eksperimen dengan skor rata-rata hasil pre-test siswa kelas kontrol pada materi pokok suhu dan perubahannya yang ditunjukkan oleh skor rata-rata pre-test kelas eksperimen dan kelas kontrol yaitu 24,7 dan 27,64 dengan skor $t_{\text {hit }}=-1,96$ berada dalam interval skor $-1,98<-1,96<1,98$ pada $\alpha=0,05$, (4) skor rata-rata hasil post-test siswa kelas eksperimen lebih tinggi secara signifikan daripada skor rata-rata hasil post-test siswa kelas kontrol pada materi pokok suhu dan perubahannya yang ditunjukkan oleh skor rata-rata hasil post-test kelas eksperimen dan kelas kontrol yaitu sebesar 62,86 dan 50,29 dengan skor $t_{\text {hit }}=8,12>t_{\text {tab }}=1,98$ pada $\alpha=0,05$, (5) skor rata-rata gain (peningkatan) hasil belajar IPA siswa kelas eksperimen lebih tinggi secara signifikan daripada skor rata-rata gain (peningkatan) hasil belajar IPA siswa kelas kontrol pada materi pokok suhu dan perubahannya, yang ditunjukkan oleh skor rata-rata gain kelas eksperimen dan kelas kontrol yaitu sebesar 0,5 dan 0,31 dengan skor $\mathrm{t}_{\text {hit }}=9,17>\mathrm{t}_{\mathrm{tab}}=1,98$ pada $\alpha=0,05$. 


\section{DAFTAR PUSTAKA}

Arisona \& Erniwati, 2013. Pengembangan Bahan Ajar IPA-Fisika Interaktif Model E-Learning Berbasis Web Pada Sekolah Menengah Pertama (SMP/MTs) se Kota Kendari sebagai Sekolah Laboratorium Pembelajaran bagi Mahasiswa Pendidikan MIPA-FKIP Unhalu. Iqbal-site17.blogspot.com.

Aziz R., 2013. Skripsi: Pengaruh Penggunaan Multimedia Interaktif Berbasis WEB Terhadap Peningkatan Hasil Belajar Siswa Pada Mata Pelajaran TIK. Repository.upi.edu.

Dodon, Y,.2013. Blended Learning: Model Pembelajaran Kombinasi E-Learning Dalam Pendidikan Jarak Jauh. Universitas Andalas

Prakash A. Bhadane, 2013. Interfacing of Java 3D Objects for Virtual Physics Lab (VP Lab) Setup for Encouraging Physics Studies. IOSR Journal of Applied Physics (IOSR-JAP). e-ISSN: 2278-4861. Volume 4 Issue 5 PP 01-06. www.iosrjournals.org.

Zhang D., 2005. Instructional Video in E-learning: Assessing the Impact of Interactive Video on Learning Effectiveness. Delft University of Technology. Netherlands. 